\title{
TEMPERATURE AND SUBSTRATE INFLUENCES ON SEED GERMINATION AND SEEDLING FORMATION IN Callisthene fasciculata Mart. (VOCHYSIACEAE) IN THE LABORATORY ${ }^{1}$
}

\author{
Ademir Kleber Morbeck Oliveira², Simone Alves Souza ${ }^{3}$, Juliana Santos Souza ${ }^{3}$ e Junior Manoel Braga \\ Carvalho $^{3}$
}

\begin{abstract}
Callisthene fasciculata Mart. is a tree belonging to the Vochysiaceae family. Its wood is moderately heavy and resistant and used to make poles, beams, and other structures. The aim of this work was to evaluate seed germination and the initial growth of seedlings of $C$. fasciculata at different temperatures and in different substrates. Seeds were collected from fruits in the Pantanal de Miranda, Mato Grosso do Sul state, Brazil. In one experiment, the seeds were subjected to constant temperatures of $20,25,30$ and $35^{\circ} \mathrm{C}$ and to alternating temperatures of $20-30$ and $25-35^{\circ} \mathrm{C}$ (on paper substrate). In another experiment, the seeds were subjected to temperatures of 20 and $25^{\circ} \mathrm{C}$ on three substrates (sand, vermiculite and between paper) in a germinator. The experiment had a randomized design, with four replicates of 25 seeds per treatment. The F-values obtained for germination indicated no significant effect of substrate or temperature on the final germination percentage. The analyses revealed no effect of a treatment interaction (temperature $\mathrm{x}$ substrate) on either germination or average germination time; however, a treatment interaction effect was observed on the germination speed index. The treatment combinations yielding the best performance were between paper substrate at $20^{\circ} \mathrm{C}$ and sand substrate at $25^{\circ} \mathrm{C}$. There was a significant effect of the interaction between temperature and substrate on seedling growth, with increased root growth observed in the between paper substrate at $25^{\circ} \mathrm{C}$ and increased aerial component growth in both sand at $20^{\circ} \mathrm{C}$ and vermiculite at $25^{\circ} \mathrm{C}$. The between paper treatment at $25^{\circ} \mathrm{C}$ yielded the greatest final seedling size. Between paper is the most recommended substrate for the production of seedlings due to its ease of handling and lower probability of contamination.
\end{abstract}

Keywords: Forest seeds; Pantanal; Carvão branco.

\section{INFLUÊNCIA DA TEMPERATURA E SUBSTRATO NA GERMINAÇÃO DE SEMENTES E NO CRESCIMENTO INICIAL DE PLÂNTULAS DE Callisthene fasciculata (VOCHYSIACEAE) EM LABORATÓRIO}

\begin{abstract}
RESUMO - Callisthene fasciculata Mart. é uma árvore da família Vochysiaceae com madeira moderadamente pesada e resistente, utilizada na fabricação de postes, vigas, entre outros usos. O objetivo deste trabalho foi avaliar a germinação das sementes e crescimento de plântulas em diferentes temperaturas e substratos, a partir de frutos coletados no Pantanal de Miranda, Mato Grosso do Sul. As sementes foram submetidas as temperaturas constantes de $20,25,30$ e $35^{\circ} \mathrm{C}$ e alternadas de $20-30$ e $25-35^{\circ} \mathrm{C}$ (substrato sobre papel) e posteriormente, temperaturas de 20 e $25^{\circ} \mathrm{C}$ em três substratos (areia, vermiculita e entre papel), com quatro repetições de 25 sementes por tratamento em germinador. O delineamento experimental foi o inteiramente casualizado. A análise conjunta dos dados indica que não ocorreu interação entre os tratamentos (substratos x temperatura) para as variáveis germinação e tempo médio de germinação; somente o índice de velocidade de germinação apresentou interação, sendo melhores os tratamentos entre papel $\left(20^{\circ} \mathrm{C}\right)$ e areia $\left(25^{\circ} \mathrm{C}\right)$. Em relação ao crescimento das plântulas, ocorreu efeito significativo nas interações entre tratamentos, com melhor crescimento do sistema radicular no substrato entre papel $\left(25^{\circ} \mathrm{C}\right)$, parte aérea, substrato areia $(20$
\end{abstract}

\footnotetext{
${ }^{1}$ Recebido em 21.02.2013 aceito para publicação em 07.04.2015

${ }^{2}$ Universidade Anhanguera-Uniderp, Programa de Pós-Graduação em Meio Ambiente e Desenvolvimento Regional, Campo Grande, Mato Grosso do Sul, Brasil. E-mail: <akmorbeckoliveira@gmail.com>.

${ }^{3}$ Universidade Anhanguera-Uniderp, Graduando em Ciências Biológicas, Campo Grande, Mato Grosso do Sul, Brasil. E-mail: <simone260693@hotmail.com>,<juliana.santossouza@hotmail.com>e < braga_junior@live.com>.
} 
$\left.{ }^{\circ} \mathrm{C}\right)$ e substrato vermiculita $\left(25^{\circ} \mathrm{C}\right)$. Levando-se em consideração o tamanho final das plântulas, o tratamento entre papel a $25^{\circ} \mathrm{C}$ foi o que proporcionou melhor desenvolvimento. O substrato entre papel, devido a facilidade de manuseio e menor probabilidade de contaminação, é o mais recomendado para a produção de mudas.

Palavras-chave: Sementes florestais; Pantanal; Carvão branco.

\section{INTRODUCTION}

Seed germination is a key component of plant management; however, little is known about the management of seeds in most native species, despite a large increase in research on the plant species of Brazilian ecosystems in recent years (FERREIRA; BORGHETTI, 2004; BRASIL, 2009; BRANCALION et al., 2010).

According to Ferreira and Borghetti (2004) and Carvalho and Nakagawa (2012), germination is considered to be the resumption of metabolic activity in the seed. Germination is influenced by environmental factors, such as temperature and light, that affect the water absorption rate and biochemical reactions. These factors can be manipulated to improve the percentage, speed and uniformity of germination to produce more homogeneous seedlings and reduce production costs in the laboratory and the field.

Temperature is one environmental factor that influences germination. However, there is not a single standard temperature for all species. Native Brazilian plants can germinate under a wide range of temperatures, depending on the biome and region, with most tropical species showing good germination performance between 20 and $35^{\circ} \mathrm{C}$ (LARCHER, 2003; FERREIRA; BORGHETTI, 2004; BRANCALION et al., 2010).

Different temperatures have various effects on seed behavior: (1) no germination occurs at low temperatures; i.e., below the minimum germination temperature; (2) the process can be accelerated by increasing the temperature within the below-optimal range; (3) the rate of germination may decrease with increasing temperature in the supra-optimal range; and, (4) no germination occurs when the temperature is too high; i.e., above the maximum temperature (CARVALHO; NAKAGAWA, 2012; BEWLEY et al., 2013). According to Marcos Filho (2005), the optimal temperature is that which enables the maximum rate of germination in the shortest period of time.

Similarly, the substrate type used for germination and subsequent seedling growth influences the water holding capacity, degree of aeration and pathogen infestation. Substrates must remain evenly moist to supply seeds with the amount of water required for germination; excess water can accelerate deterioration by providing favorable conditions for the growth of microorganisms, whereas a lack of water can interrupt important metabolic processes (BRASIL, 2009; CARVALHO; NAKAGAWA, 2012).

Little information is available on the germination process in Callisthene fasciculata Mart., which belongs to the Vochysiaceae family. This tree ranges in height between 7-18 $\mathrm{m}$ and is popularly known as "carvão branco", "carvoeiro", "itapicuru" and "capitão do campo". It is distributed in the states of Minas Gerais, São Paulo, Goiás and Mato Grosso do Sul and is abundant in the Cerrado biome and in the transition between Cerrado and semi-deciduous broadleaf forest in areas of secondary formation (POTT; POTT, 1994; LORENZI, 2008).

The species has ornamental potential for afforestation, especially when it is in bloom. Its wood has economic value and is used for external structures, such as fence posts, bridge rafters, and posts; in addition, it used for firewood and power generation (coal) (LORENZI, 2008). Stem-bark decoction of this species is also traditionally used by the inhabitants of the Pantanal as medicine, indicated for symptoms related to hepatitis, jaundice and anemia (GUARIM NETO, 2006).

Considering the wide use of Callisthene fasciculata and the paucity of information about its germination, the aim of this study was to evaluate seed germination and seedling growth in this species at different temperatures and in different substrates.

\section{MATERIALAND METHODS}

Seeds were obtained during August and September 2011 from 13 arrays located at an altitude of $177 \mathrm{~m}$ on the farm Baia Grande (20.40886'S, 056.34168'W), Pantanal de Miranda Mato Grosso do Sul. Using pruning shears, fruits were collected from different trees during initial dehiscence (grayish color, partially opened).

Revista Árvore, Viçosa-MG, v.39, n.3, p.487-495, 2015

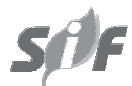


They were stored in paper bags and transported to the Research Laboratory (Biodiversity and Environmental Systems) at the Anhanguera-Uniderp University, Campo Grande, MS.

The study was divided into two stages. In the first stage, fruits and seeds were collected in August, and in the second stage, they were collected in September. In the laboratory, the collected fruits were placed on a countertop and, after their spontaneous opening, their seeds were collected and sorted. We selected seeds that showed no evidence of predation and that were not shriveled. Each fruit contained 3-4 seeds.

A humidity test was performed for each collection according to the hothouse method at $105^{\circ} \mathrm{C}$ (BRASIL, 2009), using four replicates of 25 seeds.

For the germination test, the seeds were superficially disinfected by immersion in a sodium hypochlorite solution $(2 \%)$ for three minutes and then washed in running water for one minute.

In the first experiment, we used a total of 600 seeds, and we subjected them to constant temperatures of $20,25,30$ and $35^{\circ} \mathrm{C}$ as well as alternating temperatures of 20-30 and $25-35^{\circ} \mathrm{C}$, with four replicates of 25 seeds per treatment. Seeds were placed in transparent plastic boxes $(11 \times 11 \times 3.5 \mathrm{~cm})$ on two sheets of Germitest ${ }^{\circledR}$ paper moistened with the fungicide Rovral SC® $0.1 \%$ $(\mathrm{w} / \mathrm{v})$ at a volume of 2.5 times the dry weight of the substrate. The seeds were subjected to a photoperiod of 12 hours of white light (four fluorescent lamps of $20 \mathrm{~W}, \pm 660$ lux) in germination chambers. The experimental design was completely randomized.

For the second experiment, transparent plastic boxes were also used, and the seeds were placed on sterilized sand, on vermiculite or Germitest ${ }^{\circledR}$ paper (between paper) at a constant temperature of either 20 or $25^{\circ} \mathrm{C}$. The seeds were maintained in a germination chamber with a photoperiod of $12 \mathrm{~h}$ of white light ( \pm 660 lux) on substrates previously moistened with the fungicide Rovral SC $\AA 0.1 \%(\mathrm{~m} / \mathrm{v})$. Subsequently, the seeds were watered with distilled water, if needed. The experimental design was a $3 \times 2$ factorial scheme (substrate $\mathrm{x}$ temperature) with four replicates, and the experimental unit was 25 seeds.

Germination was evaluated every day, and a seed was considered germinated based on morphological criteria, i.e., emergence of the primary root with geotropic curvature (LABOURIAU, 1983). Germination cumulative data were calculated from the sum of germinated seeds per day. In experiment 1 , the non-germinated seeds were subjected to a tetrazolium viability test $(1 \%$ in aqueous solution; BRAZIL, 2009), which removed the seed tegument. The seeds were placed in petri dishes, fully submerged in the tetrazolium solution and maintained in the dark at $25^{\circ} \mathrm{C}$ for 12 hours. Afterwards, the seeds were sectioned and evaluated. In experiment 2 , the normal formation of seedlings was also evaluated following the criteria of the Rules for Seed Analysis (BRASIL, 2009).

The germination percentage and average germination time (AGT) were evaluated according to the procedures of Ferreira and Borghetti (2004), and the germination speed index (GSI) was assessed according to Maguire (1962). We also evaluated the medium length of the primary root, shoot and total seedling size of all germinated individuals in the germination test in millimeters using a digital caliper.

Initially, the data were tested for normality requirements (Shapiro-Wilk test). Subsequently, the germination data were arcsine transformed $(\mathrm{x} / 100)^{0.5}$; the untransformed data are presented in the table 1 and 2 for clarity. The data were subjected to analysis of variance; where significant differences were found, paired means were compared using the Tukey test at the 5\% significance level. All statistical analyzes were conducted using the statistical program Assistat 7.7 beta.

\section{RESULTS}

The collected seeds showed $26.8 \%$ and $24.9 \%$ water content in experiments 1 and 2, respectively.

\subsection{Experiment 1}

The onset of germination, considered as time of protrusion of the primary root, began after eight days. Germination was fully complete after 46 days. At 20 and $30^{\circ} \mathrm{C}$, germination began on the $11^{\text {th }}$ day. At $25^{\circ} \mathrm{C}$ and at $20-30{ }^{\circ} \mathrm{C}$, it began on the $8^{\text {th }}$ day, and at 25 $35^{\circ} \mathrm{C}$, it began on the $18^{\text {th }}$ day. Seed germination was accelerated at temperatures of 20,25 and $20-30{ }^{\circ} \mathrm{C}$. Between the seventeenth and twenty-second day, a peak in germination occurred in the temperatures of 20,25 and $20-30{ }^{\circ} \mathrm{C}$, with a $40 \%$ increase over a fiveday interval (Figure 1) and the highest germination percentage occurred at 20,25 and $20-30{ }^{\circ} \mathrm{C}$ (Figure 2).

Revista Árvore, Viçosa-MG, .39, n.3, p.487-495, 2015 


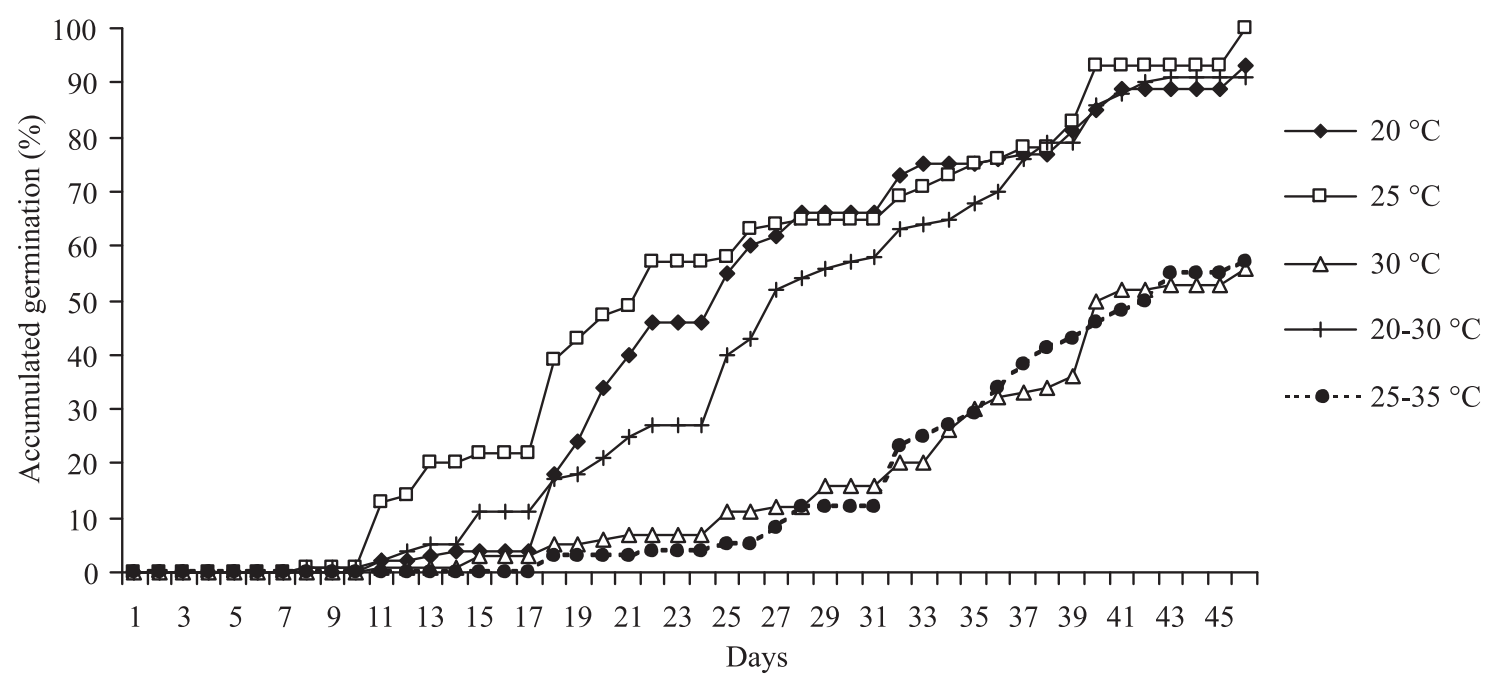

Figure 1 - Germination (\%) of Callisthene fasciculata seeds (cumulative data) at four constant temperatures and two alternating temperatures in a germination chamber.

Figura 1 - Germinação (\%) de sementes de Callisthene fasciculate (dados acumulados) em quatro temperaturas constantes e duas alternadas, em câmara de germinação.

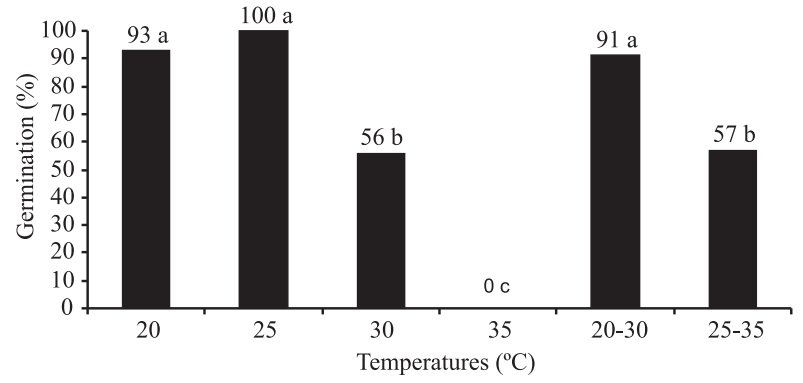

Figure 2 - Germination (\%) of Callisthene fasciculata seeds cultivated at different temperatures in a germination chamber. Average lengths followed by the same letter were not significantly different when subjected to the Tukey test, $5 \%$ probability.

Figura 2 - Germinação (\%) de sementes de Callisthene fasciculata em diferentes temperaturas, em germinador. As médias seguidas da mesma letra não diferem entre si, pelo teste de Tukey a $5 \%$ de probabilidade.

A temperature of $35^{\circ} \mathrm{C}$ led to the death of all embryos. In addition, seeds did not germinate at 30 and $25-35^{\circ} \mathrm{C}$, as observed by the tetrazolium test, which presented dead embryos.

The best AGTs were found at 20,25 and $20-30{ }^{\circ} \mathrm{C}$, being 26, 25.1 and 27.6 days, respectively. These values were significantly shorter than those of the other temperatures (Table 1).

Revista Árvore, Viçosa-MG, v.39, n.3, p.487-495, 2015
For the GSI, $25^{\circ} \mathrm{C}$ yielded a value of 4.9 and produced a large number of germinating seeds in a short time; this value was significantly different from the others (Table 1).

\subsection{Experiment 2}

Based on the results of experiment 1 , the constant temperatures of 20 and $25^{\circ} \mathrm{C}$ were chosen to test the different substrate types.

Germination, as evaluated by the emergence of the primary root, began on the sixth day on the substrates sand, vermiculite and between paper at $25^{\circ} \mathrm{C}$ and on sand at $20^{\circ} \mathrm{C}$. It began on the seventh day for vermiculite at $20^{\circ} \mathrm{C}$ and on the third day for between paper at $20^{\circ} \mathrm{C}$; the latter treatment combination showed more intense germination between the seventh and twelfth days. In addition, the change of substrates from on paper to sand, between paper and vermiculite led to a shorter time to completion of germination (17 days).

No significant treatment interaction (substrate $\mathrm{x}$ temperature) effect was found on the variables germination and AGT. An interaction effect was found for the GSI, with between paper at $20^{\circ} \mathrm{C}$ and on sand at $25^{\circ} \mathrm{C}$ yielding the best results. On the sand substrate, temperatures of 20 and $25^{\circ} \mathrm{C}$ did not statistically differ in their effects on GSI (Table 2). 
Table 1 - Germination speed index (GSI) and average germination time in days (AGT) of seeds of Callisthene fasciculata cultivated at different temperatures.

Tabela 1 - Índice de velocidade de germinação (IVG) e tempo médio de germinação em dias (TMG) das sementes da espécie Callisthene fasciculata, submetidas a diferentes temperaturas.

\begin{tabular}{ccc}
\hline Temperatures $\left({ }^{\circ} \mathrm{C}\right)$ & GSI & AGT (days) \\
\hline 20 & $3.9 \mathrm{~b}$ & $26 \mathrm{a}$ \\
25 & $4.9 \mathrm{a}$ & $25.1 \mathrm{a}$ \\
30 & $1.8 \mathrm{c}$ & $33.6 \mathrm{~b}$ \\
35 & $0 \mathrm{~d}$ & $0 \mathrm{c}$ \\
$20-30$ & $3.7 \mathrm{~b}$ & $27.6 \mathrm{a}$ \\
$25-35$ & $3.7 \mathrm{c}$ & $34.4 \mathrm{~b}$ \\
\hline
\end{tabular}

Average lengths followed by the same letter were not significantly different when subjected to Tukey's test, $5 \%$ probability.

However, the different substrates (on sand, between paper and on vermiculite) led to a change in the germination process because seeds germinated in larger quantities over a shorter period of time (Table 2) when compared with the substrate on paper.

With regards to seedling growth, the most rapid development of the primary root occurred in the between paper substrate at $25^{\circ} \mathrm{C}$, whereas the on vermiculite substrate at $25^{\circ} \mathrm{C}$ conferred the best growth of the aerial component. The largest seedling size was obtained with the between paper substrate at $25{ }^{\circ} \mathrm{C}$ ( Table 3 ).

These results demonstrate a significant interaction effect of the treatments on the growth of the primary root and aerial component and on final seedling size (Table 3). Root growth was most rapid in the between paper substrate at $25^{\circ} \mathrm{C}$, whereas the aerial component grew tallest both in the vermiculite substrate at $25^{\circ} \mathrm{C}$. The between paper treatment at $25^{\circ} \mathrm{C}$ resulted in the best development in terms of final seedling size.

The treatment temperatures and substrates did not negatively affect the normal formation of roots and the aerial component, with all of the evaluated plants presenting the basic structures of normal seedlings.

\section{DISCUSSION}

\subsection{Experiment 1}

In studying seeds of several species of the Vochysiaceae family, Salomão et al. (2003) observed differences in the percentage of water in the seeds among species such as Qualea dichotoma Warm. ex Wille (11\%), Q. grandiflora Mart. (16\%), Q. parviflora

Table 2 - Germination (G\%), germination speed index (GSI) and average germination time in days (AGT) of seeds of Callisthene fasciculata cultivated at two constant temperatures $\left(20\right.$ and $\left.25^{\circ} \mathrm{C}\right)$ on different substrates.

Tabela 2 - Germinação (G\%), índice de velocidade de germinação (IVG) e tempo médio de germinação em dias (TMG) das sementes da espécie Callisthene fasciculata, submetidas às temperaturas constantes de 20 e $25^{\circ} \mathrm{C}$, em diferentes substratos.

\begin{tabular}{|c|c|c|c|c|c|c|}
\hline Treatments & \multicolumn{2}{|c|}{$\mathrm{G}(\%)$} & \multicolumn{2}{|c|}{ GSI } & \multicolumn{2}{|c|}{ AGT (days) } \\
\hline \multicolumn{7}{|l|}{ Substrates } \\
\hline On sand & \multicolumn{2}{|c|}{95 a } & \multicolumn{2}{|c|}{$10.7 \mathrm{a}$} & \multicolumn{2}{|c|}{$9.4 \mathrm{a}$} \\
\hline On vermiculite & \multicolumn{2}{|c|}{$97 \mathrm{a}$} & \multicolumn{2}{|c|}{$9.7 \mathrm{~b}$} & \multicolumn{2}{|c|}{$10.5 \mathrm{~b}$} \\
\hline Between paper & \multicolumn{2}{|c|}{$97 \mathrm{a}$} & \multicolumn{2}{|c|}{$10.5 \mathrm{a}$} & \multicolumn{2}{|c|}{$11.4 \mathrm{c}$} \\
\hline DMS & \multicolumn{2}{|c|}{$4.38(\mathrm{p}>=.05)$} & \multicolumn{2}{|c|}{$0.35(\mathrm{p}<.01)$} & \multicolumn{2}{|c|}{$0.46(\mathrm{p}<.01)$} \\
\hline \multicolumn{7}{|l|}{ Temperature $\left({ }^{\circ} \mathrm{C}\right)$} \\
\hline 20 & \multicolumn{2}{|c|}{96 a } & \multicolumn{2}{|c|}{$10.6 \mathrm{a}$} & \multicolumn{2}{|c|}{$10.6 \mathrm{~b}$} \\
\hline 25 & \multicolumn{2}{|c|}{$97 \mathrm{a}$} & \multicolumn{2}{|c|}{$10 \mathrm{~b}$} & \multicolumn{2}{|c|}{$10.3 \mathrm{a}$} \\
\hline DMS & \multicolumn{2}{|c|}{$2.94(\mathrm{p}>=.05)$} & \multicolumn{2}{|c|}{$0.23(\mathrm{p}<.01)$} & \multicolumn{2}{|c|}{$0.31(.01=<\mathrm{p}<.05)$} \\
\hline \multicolumn{7}{|l|}{ Interaction } \\
\hline & $20^{\circ} \mathrm{C}$ & $25^{\circ} \mathrm{C}$ & $20{ }^{\circ} \mathrm{C}$ & $25^{\circ} \mathrm{C}$ & $20{ }^{\circ} \mathrm{C}$ & $25^{\circ} \mathrm{C}$ \\
\hline On sand & 95 & 95 & $10.7 \mathrm{bA}$ & $10.8 \mathrm{aA}$ & 9.6 & 9.3 \\
\hline On vermiculite & 95 & 100 & $9.3 \mathrm{cB}$ & $10.1 \mathrm{bA}$ & 10.5 & 10.5 \\
\hline \multirow[t]{2}{*}{ Between paper } & 98 & 96 & $11.8 \mathrm{aA}$ & $9.2 \mathrm{cB}$ & 11.8 & 11 \\
\hline & $\mathrm{ns}$ & $\mathrm{ns}$ & column 0,5 & line 0.4 & ns & $\mathrm{ns}$ \\
\hline DMS & $(\mathrm{p}>=.05)$ & $(p>=.05)$ & $(\mathrm{p}<.01)$ & $(\mathrm{p}<.01)$ & $(\mathrm{p}>=.05)$ & $(\mathrm{p}>=.05)$ \\
\hline
\end{tabular}

DMS $=$ value of the least significant difference for the chosen test, DMS $=$ TSD (Tukey Significant Difference). Means followed by the same lower case letter within a column and in uppercase within a line do not differ significantly from each other based on the Tukey test $(\mathrm{p}>0.05)$.

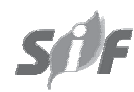

Revista Árvore, Viçosa-MG, .39, n.3, p.487-495, 2015 
Table 3 - Average lengths of primary roots, aerial part and seedlings ( $\mathrm{mm}$ ) of Callisthene fasciculata cultivated at two constant temperatures $\left(20\right.$ and $\left.25^{\circ} \mathrm{C}\right)$ in different substrates.

Tabela 3 - Tamanho médio das raízes primárias, partes aéreas e plântulas ( $\mathrm{mm}$ ) da espécie Callisthene fasciculata, submetidas às temperaturas constantes de 20 e $25^{\circ} \mathrm{C}$, em diferentes substratos.

\begin{tabular}{|c|c|c|c|c|c|c|}
\hline Treatments & \multicolumn{2}{|c|}{ Primary roots } & \multicolumn{2}{|c|}{ Aerial part } & \multicolumn{2}{|c|}{ Seedlings } \\
\hline & $20^{\circ} \mathrm{C}$ & $25^{\circ} \mathrm{C}$ & $20^{\circ} \mathrm{C}$ & $25^{\circ} \mathrm{C}$ & $20^{\circ} \mathrm{C}$ & $25^{\circ} \mathrm{C}$ \\
\hline On sand & $5.5 \mathrm{cB}$ & $7 \mathrm{bA}$ & $7.1 \mathrm{aA}$ & $7.3 \mathrm{bA}$ & $12.7 \mathrm{cB}$ & $14.3 \mathrm{cA}$ \\
\hline On vermiculite & $7.7 \mathrm{bA}$ & $7.8 \mathrm{bA}$ & $7.2 \mathrm{aB}$ & $8.6 \mathrm{aA}$ & $14.6 \mathrm{bB}$ & $16.5 \mathrm{bA}$ \\
\hline Between paper & $8.9 \mathrm{aB}$ & $16 \mathrm{aA}$ & $6.8 \mathrm{aB}$ & $7.5 \mathrm{bA}$ & $15.7 \mathrm{aB}$ & $23.7 \mathrm{aA}$ \\
\hline DMS & $\begin{array}{l}\text { column } 0.86 \\
\quad(p<.01)\end{array}$ & $\begin{array}{l}\text { line } 0.71 \\
(\mathrm{p}<.01)\end{array}$ & $\begin{array}{l}\text { column } 0.45 \\
(p<.01)\end{array}$ & $\begin{array}{l}\text { line } 0.37 \\
(p<.01)\end{array}$ & $\begin{array}{l}\text { column } 0.70 \\
(p<.01)\end{array}$ & $\begin{array}{l}\text { line } 0.57 \\
(p<.01)\end{array}$ \\
\hline
\end{tabular}

DMS $=$ value of the least significant difference for the chosen test, DMS = TSD (Tukey Significant Difference). Means followed by the same lower case letter within a column and in uppercase within a line do not differ significantly from each other based on the Tukey test $(\mathrm{p}>0.05)$.

Mart. (19\%), Vochysia haenkeana Mart. (12\%) and V. rufa Mart. (9.4\%). Although the seed water content of C. fasciculata observed in the present study exceeded most of these values, it had no negative effect on the final germination percentage in either experiment. However, the sampling period of the target species may influence the water content and consequently, the germination process. The differences in water percentage among the different species can be explained by their genetic characteristics because each species is adapted to its place of origin.

Lorenzi (2008) found that the germination of $C$. fasciculata on a sandy substrate occurred between 5 and 7 weeks, with a low germination rate. The present study was conducted under different conditions, with germination occurring over a shorter time period and at a high percentage in the laboratory. However, Lorenzi (2008) does not specify the temperature applied during the evaluation. Because our study utilized different conditions, the higher rate and speed of germination observed is not unexpected.

As the fruits of the first and second experiment were collected at different times, with 30 days between them, they could have differed in seed vigor, potentially affecting the results. However, the seed water contents from the two collection dates were very similar, which indicates that the seed characteristics did not substantially differ. This finding likely reflects the maturation stage of the collected fruit, which was similar between the two sampling dates.

The response of seeds to temperature varies widely depending on the species and place of origin. However, temperature is known to affect the rate, speed and uniformity of germination. In addition, temperature affects the speeds of water absorption and biochemical reactions, which in turn alter the entire germination process (CARVALHO; NAKAGAWA, 2012).

In the Cerrado biome, where C. fasciculata is common, many species have an optimal germination temperature of approximately $25^{\circ} \mathrm{C}$ (BRANCALION et al., 2010). This observation is consistent with our results, as the seeds were collected in the Pantanal of Miranda and most of the vegetation found in the Pantanal (over 60\%) is also present in the Cerrado. In addition, both regions have similar abiotic conditions (POTT et al., 2011). Thus, many species are found in both the Pantanal and in the Cerrado, despite the fact that one region is a flood plain and the other suffers periods of seasonal drought.

Other species found in the Pantanal present a similar temperature range to the ones found for C. fasciculata, such as Myracrodruon urundeuva M.Allemao, with has an optimum germination range of 20 to $30^{\circ} \mathrm{C}$ and alternating temperatures of $20-30^{\circ} \mathrm{C}$ (SILVA et al., 2002); and Guazuma ulmifolia Lam. and Cecropia glaziovii Snethl., which germinate at 25 and $30{ }^{\circ} \mathrm{C}$ (ARAÚJO NETO et al., 2002; GODÓI; TAKAKI, 2005).

The high average germination time (AGT) observed in the first experiment indicates a temporal distribution of germination. This distribution may favor the survival of seedlings in changing environments that exhibit favorable and unfavorable periods for seed establishment, thereby allowing at least some seeds to experience suitable germination conditions (BRANCALION; 
MARCOS FILHO, 2008). In the Pantanal, there is a strong seasonality, with some periods of water stress (POTT et al. 2011). The distribution of germination over a period of time may allow some seedlings to find favorable conditions for their establishment.

However, under laboratory conditions, germination over a prolonged period of time can be detrimental. For example, the seeds can be attacked by fungi, potentially leading to their death. Therefore, seeds with the highest germination speed will suffer less from the influence of pathogens (SCREMIN-DIAS et al., 2006), benefitting the germination process.

The higher temperatures used in this study (i.e., constant $30^{\circ} \mathrm{C}$ and alternating $25-35^{\circ} \mathrm{C}$ ) impaired seed germination performance. Moreover, $35^{\circ} \mathrm{C}$ caused the death of the embryos, as shown by the tetrazolium test. Likewise, the seeds that did not germinate at 30 and $25-35^{\circ} \mathrm{C}$ were also killed. This reduced germination rate was probably caused by enzymatic changes that impeded embryonic development by reducing the amount of free amino acids, modifying reaction speed, denaturing proteins or increasing the consumption of reserves, as reported by Marcos Filho (2005), Albuquerque (2009) and Akman (2009).

\subsection{Experiment 2}

Despite their different characteristics, all the investigated substrates were suitable for the production of seedlings, which indicates that $C$. fasciculata has a high degree of adaptability in initiating growth under different conditions. Lorenzi (2008) states that seedling development in this species is "very difficult" in gantry conditions; however, in the laboratory conditions of the present study, the production of seedlings and their initial growth showed no difficulties.

According to Silva et al. (2001), although substrate characteristics can vary, the ideal substrate should be free of pathogens, be rich in essential nutrients, have an approximately neutral $\mathrm{pH}$, have good texture and structure and exhibit an appropriate balance between water availability and aeration. All these qualities can increase the speed and uniformity of germination.

The germination of seeds is substrate-dependent. For example, Bocchese et al. (2008) studied Tabebuia heptaphylla (Vell.) Toledo in different substrates and found that the clayey substrate was more effective for germination than sandy soil. Similarly, Oliveira and Farias (2009) tested the germination of Terminalia argentea Mart. seeds in five substrates and found that clayey or sandy soil substrates were yielded more germination than filter paper, vermiculite or sand.

In addition, Alves et al. (2002) worked with Mimosa caesalpiniifolia Benth. and reported that a temperature of $25^{\circ} \mathrm{C}$ was more suitable for germination and vigor tests on seeds, regardless of substrate. A similar result was observed by Pacheco et al. (2006) with the seeds of Myracrodruon urundeuva Allemão, where temperatures of 25 and $27^{\circ} \mathrm{C}$ resulted in satisfactory seed germination on all substrates except for paper.

Moreover, the emergence of $C$. fasciculata in a greenhouse with a sandy substrate spanned between five and seven weeks, and a low germination rate was observed (LORENZI, 2008). The rate and speed of germination under the ideal laboratory conditions of the present study were higher, demonstrating that it is possible to produce a large number of seedlings in a short period of time.

Guedes and Alves (2011) experimented with seeds of Chorisia glaziovii (Kuntze) E. Santos on a paper substrate and found that temperatures of 25, 30 and 20-30 ${ }^{\circ} \mathrm{C}$ were most suitable for the growth (length) of the primary root of this species. Similar results were observed in our work with C. fasciculata seeds.

The growth in length of the primary root is usually viable under a wide range of temperatures, varying at least from 2 to $5^{\circ} \mathrm{C}$ for woody species of the temperate zone and above $10^{\circ} \mathrm{C}$ for tropical plants (LARCHER, 2003). The optimum temperature for cell division is approximately $30^{\circ} \mathrm{C}$ for most species, near the optimum temperature for growth (FERREIRA; BORGHETTI, 2004); however, the present work found that temperatures of 20 and $25^{\circ} \mathrm{C}$ were most appropriate for the studied species.

Although the seed germination experiments are theoretically similar, our results highlight the need to conduct similar experiments with native species, allowing the ideal propagation conditions for each species to be identified. According to the results obtained on

Revista Árvore, Viçosa-MG, .39, n.3, p.487-495, 2015 
germination and seedling production, C. fasciculata has a good potential for use in the reforestation of deforested areas.

\section{CONCLUSION}

Considering the evaluated parameters, the optimal conditions for germination in C. fasciculata were between paper at $20^{\circ} \mathrm{C}$ and on sand at $25^{\circ} \mathrm{C}$. For seedling formation, the optimal treatment was between paper at $25^{\circ} \mathrm{C}$. These findings demonstrate that this species has different optimal initial conditions at different stages. Due to its ease of handling and the lower likelihood of contamination, the between paper substrate is the substrate most highly recommended for the production of seedlings.

\section{ACKNOWLEDGMENTS}

The authors thank Anhanguera-Uniderp University for funding the GIP project (Interdisciplinary Research Group) and for granting a scientific initiation scholarship (PIC). In addition, the authors are grateful to the National Council for Scientific and Technological Development (CNPq) for a scientific initiation grant (PIBIC) and a productivity scholarship.

\section{REFERENCES}

AKMAN, Z. Comparison of high temperature tolerance in maize, rice and sorghum seeds by plant growth regulators. Journal of Animal and

Veterinary Advances, v.8, n.2, p.358-361, 2009.

ALBUQUERQUE, K.S.; GUIMARÃES, R.M.; ALMEIDA, I.F.; CLEMENTE, A.C.S. Alterações bioquímicas durante a embebição de sementes de sucupira-preta (Bowdichia virgilioides Kunth.).

Revista Brasileira de Sementes, v.31, n.1, p.12-19, 2009.

ALVES, E.U.; PAULA R.C.; OLIVEIRA, A.P.; BRUNO, R.L.A.; DINIZ, A.A. Germinação de sementes de Mimosa caesalpiniifolia Benth. em diferentes substratos e temperaturas. Revista Brasileira de Sementes, v.24, n.1, p.169-178, 2002.

ARAÚJO-NETO, J.C.; AGUIAR, I.B.; FERREIRA, V.M. Temperaturas cardeais e efeito da luz na germinação de sementes de mutamba. Revista Brasileira de Engenharia Agrícola e Ambiental, v.6, n.3, p.460-465, 2002.

Revista Árvore, Viçosa-MG, v.39, n.3, p.487-495, 2015
BEWLEY, J.D.; BRADFORD, K.; HILHORST, H.; NONOGAKI, H. Seeds: physiology of development, germination and dormancy. 3rd. New York: Springer, 2013. 392p.

BOCCHESE, R.A.; OLIVEIRA, A.K.M.; MELOTTO, A.M.; FERNANDES, V.; LAURA, V.A. Efeito de diferentes tipos de solos na germinação de sementes de Tabebuia heptaphylla, em casa telada. Cerne, v.14, n.1, p.62-67, 2008.

BRANCALION, P.H.S.; MARCOS FILHO, J. Distribuição da germinação no tempo: causas e importância para a sobrevivência das plantas em ambientes naturais. Informativo ABRATES, v.18, n.1, 2, 3, p.11-17, 2008.

BRANCALION, P.H.S.; NOVEMBRE, A.D.L.C.; RODRIGUES, R.R. Temperatura ótima de germinação de sementes de espécies arbóreas brasileiras. Revista Brasileira de Sementes, v.32, n.4, p.15-21, 2010.

BRASIL. Ministério da Agricultura, Pecuária e Abastecimento. Regras para análise de sementes. Brasília: Secretaria de Defesa Agropecuária/Mapa/ACS, 2009. 395p.

CARVALHO, N.M.; NAKAGAWA, J. Sementes: ciência, tecnologia e produção. 5.ed. Jaboticabal: FUNEP, 2012. 590p.

FERREIRA, A.G.; BORGHETTI, F. Germinação: do básico ao aplicado. Porto Alegre: Artmed, 2004. 323p.

GODOI, S.; TAKAKI, M. Efeito da temperatura e a participação do fitocromo no controle da germinação de sementes de embaúba. Revista Brasileira de Sementes, v.27, n.2, p.87-90, 2005.

GUARIM NETO, G. Saber tradicional pantaneiro: as plantas medicinais e a educação ambiental. Revista Eletrônica do Mestrado em Educação Ambiental, v.17, p.71-89, 2006.

GUEDES, R.S.; ALVES, E.U. Substratos e temperaturas para o teste de germinação de sementes de Chorisia glaziovii (O. Kuntze). Cerne, v.17, n.4, p.525-531, 2011. 
LABOURIAU, L.G. A germinação das sementes. Washington: OEA, 1983. 174p.

LARCHER, W. Physiological plant

ecology: ecophysiology and stress physiology of functional groups. Berlin: Springer, 2003. $533 p$.

LORENZI, H. Árvores brasileiras: manual de identificação e cultivo de plantas arbóreas nativas do Brasil. 2.ed. Nova Odessa: Plantarum, 2008. v.2.355p.

MAGUIRE, J.D. Speed of germination aid in selection and evaluation for seedling and vigour. Crop Science, v.2, n.1, p.176-177, 1962.

MARCOS FILHO, J. Fisiologia de sementes de plantas cultivadas. Piracicaba: FEALQ, 2005.495p.

OLIVEIRA, A.K.M.; FARIAS, G.C. Efeito de diferentes substratos na germinação de sementes de Terminalia argentea (Combretaceae).

Revista Brasileira de Biociências, v.7, n.3, p.320-323, 2009.

PACHECO, M.V.; MATOS, V.P.; FERREIRA, R.L.C.; FELICIANO, A.L.P.; PINTO, K.M.S. Efeito de temperaturas e substratos na germinação de sementes de Myracrodruon urundeuva Fr. All. (Anacardiaceae). Revista Árvore, v.30, n.3, p.359-367, 2006.
POTT, A.; POTT, V.J. Plantas do Pantanal. Corumbá: Empresa Brasileira de Pesquisa Agropecuária, Centro de Pesquisa Agropecuária do Pantanal, 1994. 320p.

POTT, A.; OLIVEIRA, A.K.M.; DAMASCENOJUNIOR, G.A.; SILVA, J.S.V. Plant diversity of the Pantanal wetland. Brazilian Journal of Biology, v.71, n.1, p.265-273, 2011.

SALOMÃO, A.N.; SILVA, J.C.S.; DAVIDE, A.C.; GONZALES, S.; TORRES, R.A.A.; WETZEL, M.M.V.S.; FIRETTI, F.; CALDAS, L.S.

Germinação de sementes e produção de mudas de plantas do cerrado. Brasília: Rede de sementes do Cerrado, 2003. 96p.

SCREMIN-DIAS, E.; KALIFE, C.; MENEGUCCI, Z.R.H.; SOUZA, P.R. Produção de mudas de espécies florestais nativas: manual. Campo Grande: UFMS, 2006. 59p.

SILVA, R.P.; PEIXOTO, J.R.; JUNQUEIRA, N.T.V. Influência de diversos substratos no desenvolvimento de muda de maracujazeiro-azedo (Passiflora edulis Sims f. flavicarpa Deg).

Revista Brasileira de Fruticultura, v.23, n.2, p.377-381, 2001.

SILVA, L.M.M.; RODRIGUES T.J.D.; AGUIAR, I.B. Efeito da luz e da temperatura na germinação de sementes de aroeira (Myracrodruon urundeuva Allemão). Revista Árvore, v.26, n.6, p.691-697, 2002. 